\title{
KINETICS OF Chlorella sp GROWTH MODELS IN REDUCING $\mathrm{CO}_{2}$ EMISSIONS
}

\author{
Okik Hendriyanto Cahyonugroho ${ }^{1, *}$, Dwi Dipta Yuniawati ${ }^{1}$ \\ and Euis Nurul Hidayah ${ }^{1}$ \\ ${ }^{1}$ Department of Environmental Engineering, University of Pembangunan Nasional "Veteran" \\ Jawa Timur, 60294, Indonesia \\ *E-mail: okikhc@upnjatim.ac.id
}

\begin{abstract}
$\mathrm{CO}_{2}$ emissions resulting from human activities are relatively higher concentrations that disrupt the equilibrium system in the air and ultimately damage the environment and human well-being. One environmentally friendly solution for $\mathrm{CO}_{2}$ gas removal is to use microalgae (Chlorella sp.). Chlorella sp. in photobioreactors has the ability to biofixate $\mathrm{CO}_{2}$ gas. Chlorella sp. was chosen because of the most numerous in freshwater and seawater. The purpose of this study was to determine the kinetic model of the effect of adding substrate concentrations and flow rate variations on the growth and development rates of Chlorella sp. due to exposure to pure $\mathrm{CO}_{2}$ gas emissions. This study uses pure $\mathrm{CO}_{2}$ gas with a flow rate of $0.02 \mathrm{~L} / \mathrm{min}, 0.04 \mathrm{~L} / \mathrm{min}, 0.06 \mathrm{~L} / \mathrm{min}, 0.08 \mathrm{~L} / \mathrm{min}, 0.1 \mathrm{~L} / \mathrm{min}$ and a substrate of $350 \mathrm{mg} / \mathrm{L}, 500 \mathrm{mg} / \mathrm{L}, 650 \mathrm{mg} / \mathrm{L}, 800 \mathrm{mg} / \mathrm{L}, 950 \mathrm{mg} / \mathrm{L}$ on a laboratory scale. The results showed that the most optimum growth rate occurred at the addition of substrate concentrations of $800 \mathrm{mg} / \mathrm{L}$ with a flow rate of 0.08 $\mathrm{L} / \mathrm{min}$.
\end{abstract}

Keywords: $\mathrm{CO}_{2}$ Emission, Chlorella sp, Photobioreactors, Kinetic Models

(C) RASĀYAN. All rights reserved

\section{INTRODUCTION}

The phenomenon of global warming is characterized by a gradual rise in the average temperature of the earth. Temperature changes occur in the long run slowly, but over time will be felt and have a big effect. Increased global warming due to air pollution by high $\mathrm{CO}_{2}$. Where carbon dioxide is a colorless gas found in the atmosphere with amounts reaching $330 \mathrm{ppm}$ and most comes from burning fossil fuels. ${ }^{1}$

Research began in the 90s in anticipation of increasing flue gas globally directed to find solutions, one of which was carried out using cyanobacteria and microalgae biological activity because of its reliability in fixing $\mathrm{CO}_{2}$ through photosynthesis reactions with the help of light energy. ${ }^{2}$ Microalgae-based $\mathrm{CO}_{2}$ fixation technology that has been widely developed is photobioreactor technology. ${ }^{3}$ Photosynthesis is generally defined as the process of forming new chemical compounds using light energy consisting of light and dark reactions. During the light reaction, the light energy is captured, whereas in the dark reaction that is the energy used to capture $\mathrm{CO}_{2}$ from the air.

Microalgae is the most efficient plant in capturing, utilizing solar energy, and $\mathrm{CO}_{2}$ for photosynthesis purposes. ${ }^{4}$ Microalgae are single-celled microscopic plants that can absorb $\mathrm{CO}_{2}$ in an effort to reduce concentrations of $\mathrm{CO}_{2}$ in the air. ${ }^{5}$ Carbon dioxide through the process of photosynthesis with the help of sunlight is converted into oxygen, so that the amount of carbon dioxide that enters the system will be reduced when it exits the microalgae system. Green cells such as leaves that contain lots of chlorophyll which are used by algae to capture light to synthesize carbon sourced from carbon dioxide $\left(\mathrm{CO}_{2}\right)$. Microalgae can fix $\mathrm{CO}_{2}\left(10\right.$ - 50) times more efficient compared to plants. ${ }^{6}$ Microalgae breeding to obtain high cell density is carried out in microalgae biotechnology with optimal reactor designs and processes. ${ }^{7}$ Chlorella sp. including one group of green algae which have a structure similar to plants, one of which is a cell wall composed of cellulose. In this study, Chlorella sp. used because it is able to fix $\mathrm{CO}_{2}$, rapid growth rate, as well as the production of biomass produced, is very beneficial for life. ${ }^{8}$

Rasayan J. Chem., 12(4), 2306-2310(2019)

http://dx.doi.org/10.31788/RJC.2019.1245439

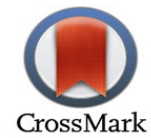


Microbial growth is characterized by an increase in microbial cells due to the availability of nutrients. In the previous studies ${ }^{2}$, to predict the relationship between the growth of Chlorella Vulgaris Buitenzorgwith the substrate in the media is using a general equation model, one of which is the Monod equation model. Microbial growth can be measured by looking at the increase in biomass or the number of cells usually following a certain growth pattern in the form of a sigmoid growth curve (monod model). In order to investigate the mechanism of sorption and potential controlling steps such as mass transport, several kinetic models were tested including the pseudo-first-order kinetic model, the Elovich model and the pseudo-second-order kinetic model for a batch contact time process ${ }^{9}$, but the monod equation is simpler and is commonly used with the relationship of growth rate and substrate concentration. ${ }^{10}$ Kinetic studies are needed to describe the efficacy of biosorption. It is necessary to recognize the mechanism of biosorption. ${ }^{11}$ Therefore this study was conducted to determine the removal of $\mathrm{CO}_{2}$ gas by microalgae (Chlorella sp.) Using photobioreactor technology with the Monod equation model to determine the optimal $\mathrm{CO}_{2}$ absorption in microalgae (Chlorella sp.).

\section{EXPERIMENTAL}

This research was to determine the kinetic model of the effect of adding substrate concentrations and flow rate variations on the growth and development rates of Chlorella $s p$. due to exposure to pure $\mathrm{CO}_{2}$ gas emissions. The reactor used is a closed container with a diameter of $12 \mathrm{~cm}$ and a height of $18 \mathrm{~cm}$ with a volume of 2 liters, then the reactor is placed on a stacked 5 rack. The reactor that contains microalgae is supplied with $\mathrm{CO}_{2}$ gas with a predetermined $\mathrm{CO}_{2}$ flow rate for approximately 8 hours.

The running process is carried out when the reactor is ready and running based on the algal life cycle. At the time of running, algae are expected to be in a homogeneous condition. Sampling is conducted every hour during the $\mathrm{CO}_{2}$ exposure process. After that, chlorophyll-a testing was done using a spectrophotometer to determine the biomass of microalgae in the reactor. During the running process, the reactor must be closed so that the reactor is not contaminated by external light or other foreign matter.

\section{Growth Rate $(\mu)$}

\section{RESULTS AND DISCUSSION}

The specific growth rate values $(\mu)\left(\right.$ day $\left.^{-1}\right)$ is obtained in Table-1.

Table-1: Specific Growth Rate Values $\left(\right.$ day $\left.^{-1}\right)$ on Variations in Substrate Concentration and Flow Rate

\begin{tabular}{c|c|c|c|c|c}
\hline \multirow{2}{*}{$\begin{array}{c}\text { Flow Rate } \\
(\mathrm{L} / \mathrm{min})\end{array}$} & \multicolumn{5}{|c}{$\mu\left(\right.$ day $\left.^{-1}\right)$} \\
\cline { 2 - 6 } & 350 & 500 & 650 & 800 & 950 \\
\hline 0.02 & 0.8231 & 0.5624 & 0.2984 & 0.8031 & 0.3682 \\
\hline 0.04 & 0.8231 & 0.2181 & 0.4004 & 0.379 & 0.6918 \\
\hline 0.06 & 0.0854 & 0.2181 & 0.4004 & 0.379 & 0.6918 \\
\hline 0.08 & 0.1503 & 0.1919 & 0.711 & 0.8375 & 0.6041 \\
\hline 0.1 & 0.7497 & 0.0598 & 0.5207 & 0.302 & 0.3896 \\
\hline
\end{tabular}

The table above shows that the highest coefficient of the linear regression is at the variation of flow rate $0.08 \mathrm{~L} / \mathrm{min}$ for substrate concentration $800 \mathrm{mg} / \mathrm{L}$, while the lowest coefficient value is at the variation of flow rate $0.06 \mathrm{~L} / \mathrm{min}$ for substrate concentration $350 \mathrm{mg} / \mathrm{L}$. Low $\mu$ values indicate slow microalgae growth, but low coefficient values can be influenced by cell density and differences in observation time. ${ }^{12}$ Fluctuations in the curve can also be caused by the sampling time of each reactor so that the growth phases are not well observed. At the addition of a large substrate concentration of $950 \mathrm{mg} / \mathrm{L}$ can not produce a high growth rate, this can be due to the substrate concentration can be an inhibitor for microorganisms.

\section{Growth Yield / Y Growth}

Yield coefficient $(\mathrm{Y})$ is the ratio of the amount of biomass production and the amount of substrate concentration used. ${ }^{13}$ By plotting the value of $\mathrm{Xm}$ (maximum biomass) with substrate concentration (So), 
RASĀYAN J. Chem.

Vol. 12 | No. 4 |2306 - 2310| October - December | 2019

the results of Growth Yield (Y) can be obtained (Fig.-1) by knowing the straight-line equation with the formed slope line is the $\mathrm{Y}$ value as shown in Table-2.

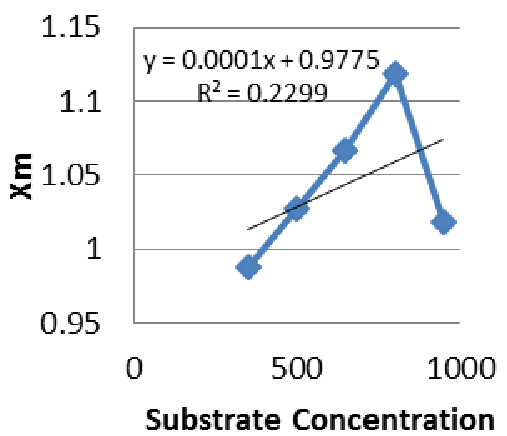

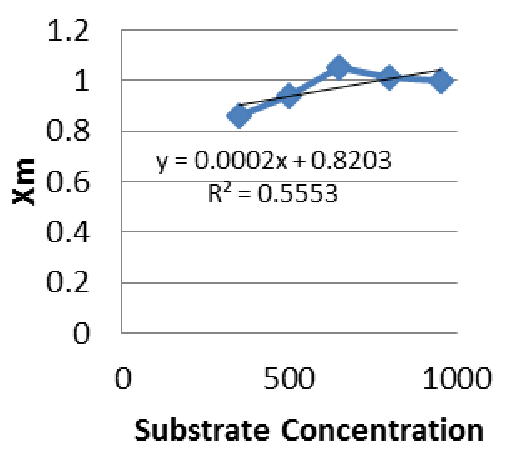
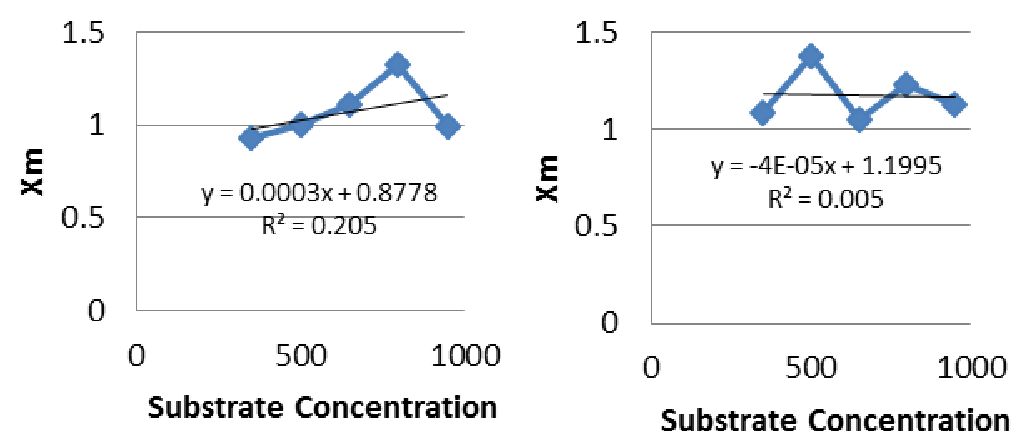

Fig.-1: The plot of Maximum Biomass (Xm) and Substrate Concentration on Flow Rate Variation.

Table-2: Growth Yield Value (Y) on Each Flow Rate Variation

\begin{tabular}{c|l|c}
\hline $\begin{array}{c}\text { Flow Rate } \\
(\mathrm{L} / \mathrm{menit})\end{array}$ & \multicolumn{1}{|c|}{ Equation } & $\begin{array}{c}\text { Growth } \\
\text { Yield }(\mathrm{Y})\end{array}$ \\
\hline 0.02 & $\mathrm{Xm}=0.0001$ So +0.9775 & 0.0001 \\
\hline 0.04 & $\mathrm{Xm}=0.0002$ So +0.8203 & 0.0002 \\
\hline 0.06 & $\mathrm{Xm}=0.0002$ So +0.9108 & 0.0002 \\
\hline 0.08 & $\mathrm{Xm}=0.0003$ So +0.8778 & 0.0003 \\
\hline 0.1 & $\mathrm{Xm}=0.00004$ So +1.1995 & 0.00004 \\
\hline
\end{tabular}

The results showed that the greater the $\mathrm{CO}_{2}$ flow rates (from $0.02 \mathrm{~L} / \mathrm{min}$ to $0.08 \mathrm{~L} / \mathrm{min}$ ), there was an increase in the value of growth yield $(\mathrm{Y})$ which reached 0,0001 to 0,0003 . This indicates that the time of $\mathrm{CO}_{2}$ exposure of $0.08 \mathrm{~L} / \mathrm{min}$, there was a large conversion of new cells with an increase in chlorophyll-a concentration in algae. However, at the highest flow rate of $0.1 \mathrm{~L} / \mathrm{min}$ has a small $\mathrm{Y}$ coefficient value which is 0.00004 . This is due to the excessive concentration of gas which can be a barrier for algal growth.

Yield values indicate the amount of organic material that is converted into new cells. ${ }^{14}$ The greater the flow rate used, the smaller the coefficient of $\mathrm{Y}$. A high $\mathrm{Y}$ value does not always indicate a better concentration of degradability because there are other factors that control the kinetics of biodegradation, including enzyme activity and initial substrate concentration ${ }^{11}$.

\section{Saturation Constants (Ks) and Maximum Growth Rate ( $\mu$ max)}

Ks value indicates the substrate concentration which has saturated with the growth of microorganisms. The value of Ks depends on the type of microorganisms and the type of substrate used. The maximum growth rate $(\mu \max )$ is the maximum value of the growth rate at the peak point in the exponential phase 
RASĀYAN J. Chem.

Vol. 12 | No. 4 |2306 - 2310| October - December | 2019

before entering the stationary phase. The values of $\mu$ max and Ks in each flow rate variation can be shown in Table-3.

Table-3: The Values of $\mu$ max and Ks in Each Flow Rate Variation

\begin{tabular}{c|c|c|c}
\hline $\begin{array}{c}\text { Flow rate } \\
(\mathrm{mg} / \mathrm{L})\end{array}$ & Equation & $\mu \max$ & $\mathrm{Ks}$ \\
\hline 0.02 & $1 / \mu=-642.491 / \mathrm{S}+3.1788$ & 0.315 & 202.117 \\
\hline 0.04 & $1 / \mu=-114.121 / \mathrm{S}+2.6748$ & 0.374 & 42.665 \\
\hline 0.06 & $1 / \mu=5554.71 / \mathrm{S}+5.0881$ & 0.197 & 1091.704 \\
\hline 0.08 & $1 / \mu=3280.61 / \mathrm{S}+2.4831$ & 0.403 & 1321.171 \\
\hline 0.1 & $1 / \mu=1604.11 / \mathrm{S}+2.8718$ & 0.348 & 856.983 \\
\hline
\end{tabular}

Table 3 shows that the optimum of $\mu$ max coefficients and Ks coefficients found in the $\mathrm{CO}_{2}$ flow rate of $0.08 \mathrm{~L} / \mathrm{min}$, which are 0.403 and 1321.171. That is because the substrate is in maximum concentration and the growth of microalgae will experience saturation. At a flow rate of $0.1 \mathrm{~L} / \mathrm{min}$, it can be seen that the coefficient $\mu \max$ and the Ks coefficient have decreased by 0.348 and 856.983 . This shows that microalgae are experiencing burnout and are in a phase of decay. The greater the coefficient values of $\mu \max$ and Ks indicate the concentration of the substrate will experience saturation of the growth of microalgae. Ks shows the saturation of substrate concentration on biomass growth. ${ }^{15}$ However (ks) was unaffected by ionic strength since the reaction is taking place between charged and uncharged species. ${ }^{16}$ Based on the specific growth kinetics coefficient $(\mu)$, Growth Yield (Y), saturation constant (Ks) and maximum growth rate $(\mu \max )$ show the consistency that the $\mathrm{CO}_{2}$ flow rate of $0.08 \mathrm{mg} / \mathrm{L}$ shows the optimal coefficient value in the growth of microalgae Chlorella sp the $\mathrm{CO}_{2}$ absorption process.

\section{CONCLUSION}

From the results of the research and discussion that has been described, it can be concluded that the time of exposure to $\mathrm{CO}_{2}$ gas with each variation of $\mathrm{CO}_{2}$ flow rate and the addition of substrate concentrations affect the growth of Chlorella sp. with different growth phases, but the provision of high concentrations of $\mathrm{CO}_{2}$ exposure and high substrate concentrations can be a barrier to the growth of the algae. The most optimum value of chlorophyll-a concentration occurs at the addition of a substrate concentration of 800 $\mathrm{mg} / \mathrm{L}$ with a flow rate of $0.08 \mathrm{~L} / \mathrm{min}$. Basically, the kinetic model parameters show the increasing growth rate of Chlorella sp. in removing $\mathrm{CO}_{2}$ gas. Optimum $\mathrm{CO}_{2}$ removal conditions are found at a flow rate of $0.08 \mathrm{~L} / \mathrm{min}$ and substrate concentrations of $800 \mathrm{mg} / \mathrm{L}$ which have optimal coefficients of $\mu, \mathrm{Y}$, Ks, and $\mu \max$ as well.

\section{ACKNOWLEDGMENT}

The financial support provided to this research by Research and Community Service Centre of University Pembangunan Nasional Veteran Jawa Timur(RCSC-UPN Veteran Jawa Timur), Indonesia (Contract No. SPP/95/UN.63.8/LT/V/2019) is greatly appreciated.

\section{REFERENCES}

1. A. Wijanarko, H. Hermansyah, M. Gozan, and B. A. Witarto, Biotechnology and Bioprocess Engineering Journal, 11(6), 484(2006), DOI: 10.1007/BF02932071

2. A. Wijanarko, Dianursanti, B. A. Witarto, and W. R. Soemantojo, Makara Journal of Technology, 8(2), 35(2004), DOI: 10.7454/mst.v8i2.254

3. O. H. Cahyonugroho, S. N. Nindhita., International Journal of ChemTech Research, 11(10), 08(2018), DOI: 10.20902/IJCTR.2018.111002.

4. Kasrina, S. Irawati, and Wahyu, E., Exacta Journal, 10(1), 36(2012)

5. A. Mulyanto, Indonesian Hydrosfir Journal. 5(2), 13(2010)

6. B. Wang, C. Q. Lan, M. Horsman, Biotechnol. Adv., 30(4), 904(2012) DOI:10.1016/j.biotechadv.2012.01.019

7. M. J. G. V. Barbosa, Ph.D Thesis, Wageningen University, Wageningen, The NetherlandWithsummary in Dutch, (2003). 
RASĀYAN J. Chem.

Vol. 12 | No. 4 |2306 - 2310| October - December | 2019

8. N. Sopiah, M. Adi, and S. Sindi, Journal of Environmental Technology, 14(1), 01(2013). DOI:10.29122/jtl.v14i1.1431.

9. C. Sumithra and S. Karthikeyan, Rasayan Journal of Chemistry, 7(2), 149(2014).

10. Margono, H. Sulistyo, and Sumardi, Technical Forum, pp. 65-71,(2001).

11. P. P. Kumar, Y. P. Kumar, and B. V. Rao, Rasayan Journal of Chemistry, 10(3), 1025(2017), DOI: 10.7324/RJC.2017.1031683

12. Fahria, Thesis, Department of Environmental Engineering, Faculty of Civil Engineering and Planning, National Development University, Surabaya, (2012),

13. Metcalf and Eddy, Inc., (1979), Wastewater Engineering Treatment Disposal Reuse, Mc Graw Hill, Inc., New York. pp. 234-246.

14. Wahyu, S. Istiyantyo, C. K. Andri and Silviana, In Proceedings of the National Seminar on Chemical Engineering. Bandung, Indonesia, pp. 143-150 (2014).

15. D. W.Septiani, A.Slamet, and J. Hermana, Pomits Engineering Journal, 15(3), 20(2014)

16. Salem Et. Ashoor, Fatma M. Ashoor and Noori Y. Salman, Rasayan Journal of Chemistry, 6(1), 1 (2013).

[RJC-5439/2019] 